\title{
Hillmen Color Chart
}

National Cancer Institute

\section{Source}

National Cancer Institute. Hillmen Color Chart. NCI Thesaurus. Code C132428.

A visual color scale created by Hillman et al in 2004 to enable standardization of urine color in the assessment of hemoglobinuria. (Hillmen P, Hall C, Marsh JC, Elebute M, Bombara MP, Petro BE, Cullen MJ, Richards SJ, Rollins SA, Mojcik CF, Rother RP. Effect of eculizumab on hemolysis and transfusion requirements in patients with paroxysmal nocturnal hemog lobinuria. N Engl J Med. 2004 Feb 5;350(6):552-9.) 